\title{
EVEKTIVITAS PERJANJIAN LAUT ANTARA ANAK BUAH KAPAL MENURUT UNDANG-UNDANG NOMOR 17 TAHUN 2008
}

\author{
Adriana Mustafa \\ Pengajar Fakultas Syariah dan Hukum UIN Alauddin Makassar
}

\begin{abstract}
The employment agreement is the main foundation for workers to hold a working relationship, and is the basis for the worker or workers to demand their rights. When compared with the Sea Working Agreement Working Agreement that under the Act will be found a difference. Sea Employment Agreement are specific, whereas the employment agreement under the Act are general. Sea Employment Agreement must be made before government authorities, namely Syahbandar. In the operation of ships, confirmed that the ship should be in a state seaworthy and manned by a crew of which have met the requirements for sailing. Crew and vessel employers must be aware of the rights and obligations of each, so as to create harmonious working relationship between the two sides. Employers vessel must also consider the welfare of their workers.
\end{abstract}

\section{Keywords:}

Sea Employment Agreement, Crew, Entrepreneur Ship, Welfare

\begin{abstract}
Abstrak
Perjanjian kerja merupakan landasan utama bagi pekerja untuk mengadakan suatu hubungan kerja, serta merupakan dasar bagi pekerja dan atau buruh untuk menuntut hak-haknya. Bila dibandingkan Perjanjian Kerja Laut dengan Perjanjian Kerja yang berdasarkan Undang-Undang akan ditemui suatu perbedaan. Perjanjian Kerja Laut bersifat khusus, sedangkan perjanjian kerja yang berdasarkan Undang-Undang bersifat umum. Perjanjian Kerja Laut harus dibuat dihadapan pejabat pemerintah yang berwenang yaitu Syahbandar. Dalam pengoperasian kapal laut, ditegaskan bahwa kapal harus dalam keadaan laik laut dan diawaki oleh sejumlah Awak Kapal yang telah memenuhi persyaratan untuk berlayar. Awak Kapal dan pengusaha kapal harus menyadari hak dan kewajiban masingmasing, sehingga tercipta hubungan kerja yang selaras di antara kedua belah pihak. Pengusaha kapal juga harus memperhatikan kesejahteraan hidup pekerjanya.
\end{abstract}

Kata Kunci:

Perjanjian Kerja Laut, Awak Kapal, Pengusaha Kapal, Kesejahteraan 


\section{A. PENDAHULUAN}

\section{Latar Belakang Masalah}

7 aris-Garis Besar Haluan Negara (GBHN) tahun memberi.kan visi yang merupakan tujuan yang ingin dicapai, yaitu terwujudnya masyarakat Indonesia yang damai, demokratis, berkeadilan, berdaya saing, maju dan sejahtera, dalam wadah Negara Kesatuan Republik Indonesia yang didukung oleh manusia Indonesia yang sehat, mandiri, beriman, bertakwa, berakhlak mulia, cinta tanah air, berkesadaran hukum dan lingkungan, menguasai ilmu pengetahuan teknologi, serta memiliki etos kerja yang tinggi dan berdisiplin.

Bangsa Indonesia harus menyadari bahwa pembangunan mengandung kerawanan. Kerawanan timbul sebagai akibat dari pembangunan, terutama jika rasa sosial tidak terpenuhi karena rasa keadilan sosial harus diperluas melalui pemerataan pembangunan dan hasil-hasilnya.

Perkembangan lingkungan strategis nasional dan internasional menuntut penyelenggaraan pelayaran yang sesuai dengan perkembangan ilmu pengetahuan dan teknologi, peran serta swasta dan persaingan usaha, otonomi daerah, dan akuntabilitas penyelenggara negara, dengan tetap mengutamakan keselamatan dan keamanan pelayaran demi kepentingan nasional. (Menimbang huruf d UndangUndang Nomor 17 Tahun 2008 tentang Pelayaran).

Untuk memenuhi harapan tersebut, maka perhubungan angkutan laut makin mendapat perhatian yang besar baik kalangan pemerintah maupun pihak swasta yang ingin berpartisipasi dalam pembangunan khususnya dalam bidang angkutan laut. Sejalan dengan upaya pencapaian tujuan pembangunan di bidang ekonomi dan sosial yaitu untuk meningkatkan taraf hidup yang lebih baik secara material maupun spiritual, maka diperlukan khusus terhadap faktor Sumber Daya Manusia (SDM), khususnya dalam pertindungan dan kesejahteraan tenaga kerja anak buah kapal (disingkat $\mathrm{ABK}$ ).

Dalam kaitannya dengan pembangunan perhubungan laut, maka upaya perlindungan dan keselamatan tenaga kerja yang bekerja di laut, akan tentunya dalam suatu perjanjian kerja yang disebut dengan perjanjian kerja laut. Sebagai dasar terjadinya hubungan kerja antara pekerja/buruh dengan pengusaha/majikan kapal, maka keberadaan perjanjian kerja laut diharapkan mampu menjamin hak dan kewajiban para pihak dalam perjanjian tersebut.

Namun peningkatan produktifitas dan kesejahteraan anak buah kapal (ABK) menjadi hal yang sangat sulit tercapai karena seririg kali pengusaha/majikan kapal kurang memperhatikan kesejahteraan anak buah kapalnya bahkan mengabaikan keselamatan mereka. Pengusaha kapal kadang membuat kontrak kerja yang merugikan anak buah kapal. Standar Gaji dalam perjajian kerja tersebut tidak sesuai dengan standar gaji Internasional yang sebagaimana telah ditetapkan oleh International Labour Organization (disingkat ILO) atau yang telah ditetapkan oleh International Transport Workers Federation (disingkat ITF).Gaji standar Anak Buah 
Kapal menurut ILO US \$ 871 per bulan, dan Standar ITF minimal US \$ 1.400 perbulan.Tapi kenyataan banyak anak buah kapal (ABK) Indonesia yang menerima gaji di bawah angka tersebut, dan tidak jarang pengusaha kapal mengingkari gaji yang disepakati semula setelah anak buah kapal (ABK) turun dari kapal. (KPI: Diperlukan SKB Menakertrans dan Menhub untuk Penempatan Pelaut, 2005).

Dari dasar inilah, penulis berkeinginan untuk membahas dalam suatu karya ilmiah agar diperoleh suatu gambaran dari hubungan perjanjian kerja laut dengan keselamatan kerja anak buah kapal (ABK)

\section{Rumusan Masalah}

Dengan memperhatikan latar belakang masalah di atas, maka penulis merumuskan masalah pokok sebagai berikut:

- Bagaimana hubungan hukum perjanjian kerja laut dengan perjanjian kerja yang berdasarkan Undang-Undang Ketenagakerjaan di Indonesia?

- Bagaimanakah efektivitas pelaksanaan perjanjian kerja laut terhadap keselamatan kerja awak kapal?

\section{Tujuan dan Kegunaan Penelitian}

a. Adapun tujuan yang ingin dicapai dengan penelitian ini adalah:

- Untuk mengetahui hubungan hukum perjanjian kerja laut dengan perjanjian kerja yang berdasarkan Undang-Undang Ketenagakerjaan.

- Untuk mengetahui efektivitas pelaksanaan perjanjian kerja lautterhadap keselamatan kerja awak kapal.

b. Adapun kegunaan dari penelitian ini adalah:

- Kegunaan Teoritis, yakni diharapkan dapat berguna bagi pengembangan ilmu hukum pada umumnya dan ilmu hukum dibidang perdata pada khususnya.

- Kegunaan Praktis, yakni diharapkan tulisan ini berguna bagi pihak yang berkeeimpung dalam bidang pelayaran.

\section{B. TINJAUAN PUSTAKA}

\section{Teori tentang Perjanjian Kerja Laut}

C. T. Kansil (1985:188) memberi pengertian perjanjian sebagai berikut "Perjanjian adalah suatu peristiwa dimana pihak yang satu berjanji kepada pihak yang lain untuk melaksanakan suatu hal". Sedangkan menurut R. Subekti (2002) "Perjanjian adalah suatu peristiwa dimana seorang berjanji kepada seorang lain atau dimana dua orang itu saling berjanji untuk melaksanakan suatu hal".

Pengertian perjanjian kerja menurut Pasal 1601 (a) KUHPerdata sebagai berikut:

"Perjanjian kerja adalah suatu persetujuan bahwa pihak ke satu, yaitu buruh, mengikatkan din untuk menyerahkan tenaganya kepada pihak lain, yaitu majikan, dengan upah selama waktu yang tertentu". 
Undang-Undang Nomor 13 Tahun 2003, tentang Ketenagakerjaan. Pasal 1 angka 14 memberikan pengertian yakni:

"Perjanjian kerja adalah perjanjian antara pekerja/buruh denganpengusaha atau pemberi kerja yang memuat syarat-syaratkerja, hak, dan kewajiban para pihak".

Berdasarkan rumusan Undang-Undang Nomor 13 Tahun 2003 tentang Ketenagakerjaan, KUHPerdata, dan pendapat ahli hukum C. T. Kansil dan R. Subekti mengenai perjanjian kerja, ternyata bahwa rumusan-rumusan tersebut mengandung unsur-unsur yang sama, yaitu dengan diadakannya perjanjian kerja maka timbullah hubungan antara majikan dan buruh yang menunjukkan kedudukan hukum kedua belah pihak yang pada dasarnya memberikan hak kepada buruh untuk menerima upah atas penunaian kerja sesuai waktu yang telah disepakati dan memberikan kewajiban kepada majikan untuk membayar upah atas penunaian kerja oleh buruh.

\section{Hubungan para Pihak dalam Perjanjian Kerja Laut}

Secara umum diketahui bahwa dalam suatu perjanjian terdapat dua orang atau dua pihak yang mengadakan hubungan hukum untuk melaksanakan suatu prestasi, jadi dalam suatu perjanjian senantiasa melibatkan lebih dari satu orang atau pihak yaitu pihak ketiga dengankedudukan tertentu pula. Demikian halnya dengan perjanjian kerjalaut, dengan melihat pengertian perjanjian Laut yang telah penuliskemukakan dapat ditentukan dua pihak yang menyelenggarakanperjanjian kerja laut yaitu:

a. Pengusaha kapal selaku majikan di satu pihak,

b. Nakhoda dan anak buah kapal selaku buruh dipihak lain.

Sebagaimana yang telah diuraikan terlebih dahulu bahwa perjanjian kerja laut yang dilakukan antara pengusaha kapal dengan anak buah kapal atau kelasi disyaratkan harus diselenggarakan dihadapan seorang pegawai yang ditunjukkan oleh pihak yang berwenang. Yang dimaksud dengan wakil pemerintah yang berwenang disini adalah yang ikut terlibat dalam proses pembuatan dan pelaksanaan perjanjian kerja laut. Jadi dengan demikian pihak-pihak yang terlibat dalam perjanjian kerja laut adalah:

1. Pemilik selaku pengusaha kapal;

2. Nakhoda;

3. Anak buah kapal;

4. Syahbandar.

Untuk memperjelas pihak - pihak yang terlibat dalam perjanjian kerja laut ini maka penulis akan menguraikan satu persatu.

\section{Pengusaha Kapal}

Pengertian pengusaha kapal dapat dilihat datam Pasal 320 KUH Dagang yang dirumuskan:

"Pengusaha kapal adalah dia, yang memakai sebuah kapal guna pelayaran di 
laut dan mengemudikannya sendiri atau suruh mengemudikannya oleh seorang nakhoda yang bekerja padannya".

Oleh karena praktek dalam dunia perkapalan makin lama makin banyak memperiihatkan keadaan, bahwa yang mengusahakan pelayaran tidak lain adalah para pihak pengusaha kapal, maka Pasal 320 KUHDagang diubah sedemikian rupa.

Menurut Pasal 342 KUHDagang:

"Sedemikian pemimpin kapal nakhoda harus mengambil sikap dan bertindak sesuai kecakapan dan kecermatan serta kebijaksanaan yang demikian sebagaimana diperiukan untuk melakukan tugasnya".

Pengertian nakhoda menurut Pasal 137 UU Nomor 17 Tahun 2008 tentang Pelayaran:

"Nakhoda untuk kapal motor ukuran GT 35 (tiga puluh lima Gross Tonnage) atau lebih memiliki wewenang penegakan hukum serta bertanggung jawab atas keselamatan, keamanan, dan ketertiban kapal, pelayar, dan barang muatan".

Oleh karena itu seorang nakhoda dituntut untuk mempunyai keahlian dan kecakapan khusus untuk mempunyai sebuah kapal. Selain itu nakhoda diwajibkan pula mengikuti dengan teliti kebiasaan dan peraturan yang ada untuk menjamin ketaikan mengarungi laut demi keselamatan kapal, keselamatan para penumpang dan muatan yang diangkutnya. Nakhoda tidak boleh melakukan perjalanan, kecuali apabila kapal telah memenuhi syarat untuk melakukan perjalanan itu, dilengkapi dengan pantas dan dianakbuahi secukupnya.

\section{Syarat Sahnya suatu Perjanjian Kerja Laut}

Secara umum apabila kita perhatikan Pasal 1320 KUHPerdata, maka untuk sahnya suatu perjanjian diperiukan empat syarat yaitu:

1. Kesepakatan mereka yang mengikatkan dirinya;

2. Kecakapan untuk membuat suatu perikatan;

3. Suatu pokok persoalan tertentu;

4. Suatu sebab yang tidak tertarang.

Dua syarat yang pertama yakni syarat point 1 dan 2, dinamakan syarat subjektif karena mengenai orang-orang atau subjek yang mengadakan perjanjian, sedangkan dua syarat yang terakhir yakni 3 dan 4, dinamakan syarat objektif kerena mengenai perjanjian sendiri oleh objek dari perbuatan hukum yang dilakukannya itu. Mengenai syarat subjektif, jika syarat itu tidak terpenuhi maka perjanjian itu dapat dibatalkan oleh satu pihak. Pihak tersebut yang paling cakap atau pihak yang memberikan sepakatnya secara tidak bebas.

Perjanjian kerjan laut mempunyai persamaan dengan perjanjian perburuhan pada umumnya, yakni dengan diadakannya perjanjian kerja maka timbullah hubungan hukum antara seorang buruh dengan majikan yang memberikan hak 
kepada buruh untuk menerima upah atas penunaian kerja dan penunaian kewajiban kepada majikan untuk membayar upah atas penunaian kerja oleh buruh, sesuai waktu kerja yang telah disepakati bersama.

\section{Pengertian tentang Anak Buah Kapal (ABK)}

Sebagaimana telah dibahas dalam pembahasan sebelumnya, awak kapal termasuk dalam hukum perburuhan, ini ditinjau dari segi perjanjian kerja yang diadakan, yaitu antara anak buah kapal (ABK) dengan pihak pengusaha. Istilah buruh sangat populer dalam dunia perburuhan/ketenagakerjaan, selain dari zaman penjajahan Belanda juga peraturan perundang-undangan yang lama (sebelum Undang-Undang Nomor 25 Tahun 1997 tentang Ketenagakerjaan) menggunakan istilah buruh.

\section{Pengertian Pemutusan Hubungan Kerja Laut}

Seperti halnya dengan hubungan kerja pada perusahaan pada umumnya, maka pemutusan hubungan kerja di perusahaan pelayaran dapat terjadi dengan beberapa alasan yang dapat dibenarkan oleh peraturan perundang-undangan yang berlaku, yaitu berdasarkan KUHPerdata dan KUHDagang.

Dengan demikian pemutusan hubungan kerja dapat dilakukan oleh siapa saja yang berkerja di kapal. Kemudian hal yang sangat penting yang harus dilakukan oleh perusahaan pertayaran adalah memenuhi ketentuan Pasal 1638 (a) KUHPerdata.Pasal tersebut menentukan peaisahaan pelayaran pada tiap akhir perjanjian kerja laut wajib memberikan "Surat Keterangan Berhenti". Dimana surat itu dapat dipergunakan sebagai pelengkap persyaratan bila mereka mencari pekerjaan lagi. Djoko Triyanto (2005:189)

\section{METODE PENELITIAN}

\section{Lokasi Penelitian}

Lokasi penelitian ini dilaksanakan di kota Makassar khususnya pada Kementerian Perhubungan dalam hal ini pada otoritas pelabuhan. Pemilihan lokasi ini dilakukan dengan pertimbangan karena banyaknya masalah tentang awak kapal yang tidak menerima hak sesuai yang diperjanjikan.

\section{Jenis dan Sumber Data}

a. Data Primer

Yaitu data yang diperoleh dari hasil wawancara langsung dengan kepala perhubungan dengan banyak mengadopsi dari peraturan perundang-undangan.

b. Data Sekunder

Yaitu data yang diperoleh dari bahan tertulis yang tersedia berupa literatur literatur, peraturan perundang-undangan yang mempunyai kaitan dengan topik penulisan ini. 


\section{Teknik Analisis Data}

Setelah penulis mengumpulkan data baik data primer maupun data sekunder yang berkaitan dengan topik pembahasan dalam penulisan hasil penelitian ini, maka langkah yang ditempuh selanjutnya disusun secara sistematis dengan metode kualitatif.

\section{PEMBAHASAN}

\section{Hubungan Hukum Perjanjian Kerja Laut dengan Perjanjian Kerja yang} Berdasarkan Undang-Undang Ketenagakerjaan

Berikut akan membahas perjanjian kerja pada umumnya yaitu berdasarkan Undang-Undang Ketenagakerjaan. Di dalam Pasal 1601 adalah suatu peraturan yang dibuat oleh seorang atau beberapa perkumpulan majikan yang berbadan hukum dengan seorang atau beberapa serikat pekerja/buruh yang berbadan hukum, mengenai syarat-syarat kerja yang harus diindahkan pada waktu membuat perjanjian. Menurut Pasal 1 ayat 21 UU No. 13 Tahun 2003 tentang Ketenagakerjaan, perjanjian buruh dikenal denganistilah perjanjian kerja bersama yaitu perjanjian yang merupakan hasil perundingan antara seorang pekerja/buruh atau serikat pekerja/buruh yang tercatat pada instansi yang bertanggung jawab di bidang ketenagakerjaan dengan pengusaha atau perkumpulan pengusaha yang memuat syarat-syarat kerja, hak dan kewajiban kedua belah pihak.

Kelebihan dan keuntungan dalam suatu perjanjian kerja bersama sebenamya bukanlah semata-mata memperjuangkan kepentingan pihak pekerja belaka, akan tetapi harus pula diingatkepentingan dan kondisi dari pihak majikan. Apakah dengan tuntutan itu pihak majikan nantinya akan sanggup melaksanakan kewajibannya, karena jika hanya mementingkan selah satu pihak saja, yaitu pihak pekerja tanpa menghiraukan keadaan dari pihak majikan, dan temyata pihak majikan tidak sanggup untuk melaksanakan kewajibannya, sehingga pengusahan tersebut sampai menutup perusahaannya, dan pada akhirnya pekerja/buruhlah yang ikut mengalami kerugian.

\section{Pelaksanaan Perjanjian Kerja Laut atas Keselamatan Kerja anak buah kapal (ABK)}

Menurut Rahmatullah selaku Kepala Kantor Kelaiklautan Kapal mengatakan bahwa PKL sudah terformat sejak lama yang diberikan oleh Syahbandar dan tidak dapat diubah. Hak dan kewajiban para pihak ada dalam PKL dan Undang-Undang yang berlaku. Untuk lebih jelasnya penulis akan menguraikan hak dan kewajiban masing-masing pihak.

\section{Hak-Hak Pengusaha Kapal}

a. Menurut para buruh kapal untuk melaksanakan pekerjaan dengan baik harus sesuai PKL yang telah dibuat. Rahmatullah, menjelaskan bahwa PKL ditanda tangani oleh para pihak yang sebelumnya tertebih dahulu dibacakan 
isi perjanjian tersebut oleh Syahbandar, serta menanyakan kesanggupan buruh kapal untuk bekerja dengan baik pada perusahaan. Buruh kapal harus melaksanakan pekerjaan dengan baik, sebagaimana mereka diupah untuk bekerja.

b. Perusahaan dapat menghentikan hubungan kerja dengan bunjh kapal yang sebagaimana dimaksudkan dalam Pasal 143 Undang-Undang No. 17 tahun 2008 tentang Pelayaran. Hal ini tidak tercantum di dalam PKL, Rahmatullah mengatakan bahwa apabila ABK meninggalkan kapal tanpa seizing Nakhoda, maka perusahaan akan menghentikannya dengan menghentikan upah dan tunjangan-tunjangannya, serta memperhitungkan kerugiankerugian yang terjadi termasuk biaya untuk memperoleh penggantinya. Juga apabila berdasarkan penilaian perusahaan bahwa Awak Kapal dinilai tidak cakap atau mampu dalam melaksanakan tugas-tugasnya, maka perusahaan akan menghentikannya dan ia tidak dapat menuntut dalam hal keuangan kepada perusahan.

\section{Kewajiban-Kewajiban Pengusahan Kapal}

a. Membayar upah kepada buruh kapal sesuai dengan ketentuan yang di setujui, penentuan besarnya upah bagi ABK berdasarkan UMR. Pembayaran gaji pokok bagi ABK dibayar per bulan setiap tanggal 30 (tiga puluh). Syahbandar tidak turut menentukan besarnya upah bagi Awak Kapal, melainkan ditentukan sendiri oleh pengusaha kapal berdasarkan standar Upah Minimum Regional (UMR) yang dikeluarkan oleh Departemen Tenaga Kerja (Depnaker) setempat. Syarifuddin selaku mantan ABK mengatakan bahwa upah yang diberikan pengusaha kapal sesuai standar UMR, dan jarang terjadi keteriambatan pemberian upah. Rahmatullah, menambahkan bahwa jarang terjadi pengaduan ABK mengenai keteriambatan pembayaran gaji atau pembayaran gaji kurang semestinya. Karena besarnya gaji dan pembayarannya telah disepakati sebelumnya dalamPasal 5 (a) Perjanjian Kerja Laut.

b. Menetapkan pengaturan pakerjaan bagi Awak Kapal. Pengaturan pekerjaan itu dibedakan berdasarkan jabatan masing-masing Awak Kapal.

c. Menunjuk sebuah kapal dimana Awak Kapal bertugas melaksanakan pekerjaan. Dalam Pasal 2 (a) PKL, pengusahan kapal telah menunjuk sebuah kapal yang sebagaimana akan ditempati oleh Awak Kapal untuk bekerja sesuai dengan jabatannya. Rahmatullah juga menjelaskan bahwa biasanya sering pengusaha kapal memindahkan Awak Kapalnya untuk bekerja dikapal lain akan tetapi kapal milik perusahaan yang sama, dengan alasan penyegaran dalam pelaksanaan tugas atau pembaharuan pengawakan kapal. Dan setiap perpindahan seorang Awak Kapal harus membuat PKL yang baru agar terdaftar dalam daftar bahari kapal yang baru ditugaskannya tersebut. 
d. Memberikan instruksi-instruksi kepada Awak Kapal dalam rangka penyelenggaraan pelayaran atau pengangkutan di laut. Mengenai pengaturan ini diatur dalam Bagian Keempat Peraturan Pemerintah Nomor 7 Tahun 2000 tentang Kepelautan. Rahmatullah menjelaskan bahwa hal demikian diatur oleh masing-masing perusahaan kapal tentang jadwal jam kerja secara umum, jam istirahat, jaga laut (saat kapalsedang beriayar di laut), jaga pefabuhan (saat kapai sedang sandar di Pelabuhan), pengawakan kapal dan peraturan disiplin laut di atas kapal.

e. Penjagaan kesehatan, keselamatan, keamanan dan kesusilaan bagi Awak Kapal. Rahmatullah menjelaskan bahwa dalam usaha penjagaan kesehatan bagi Awak Kapalnya, mereka menyediakan makanan yang memenuhi standar kesehatan dan tempat tinggal yang layak di atas kapal. Selain itu dijelaskan bahwa pihak perusahaan memberikan tunjangan kesehatan bagi buruh kapal yang telah bekerja lewat dari 6 (enam) bulan. Perusahaan juga wajib menyediakan makanan dan alat-alat pelayaran dalam jumlah yang cukup layak untuk setiap pelayaran. Makanan harus memenuhi jumlah, ragam serta nilai gizi dan jumlah air tawar yang cukup dan memenuhi standar kesehatan (Pasal 1, Pasal 2, Pasal 3 Peraturan Pemerintah Nomor 7 Tahun 2000, tentang Kepelautan). Perusahaan menanggung sebesar 50\% biaya pengobatan dan perawatan kesehatan buruh kapal beserta istri dan anak-anaknya (Maksimal 4 orang anak). Syarifuddin menambahkan bahwa setiap bulan diadakan pemeriksaan kesehatan bagi Awak Kapal.

\section{Hak-Hak Awak Kapal}

a. Memperoleh upah dari pengusaha kapal sesuai dengan ketentuan yang telah ditentukan. Besarnya upah yang telah disepakati dicantumkan di dalam Pasal 2 PKL, juga harus memenuhi standar UMR. Menurut Syarifuddin mengatakan jarang terjadi keterlambatan pembayaran gaji ataupun pembayaran gaji yang kurang dari seharusnya dan upah diberikan oleh perusahaan cukup pantas bag! mereka. Misalnya dalam Pasal 18 ayat (2) Peraturan Pemerintah Nomor 7 Tahun 2000, tentang Kepelautan mengenai uang delegasi. Pasal 11 PKL diatur bahwa Awak Kapal harus meninggalkan sebahagian dari gaji pokoknya tiap bulan untuk dibayarkan oleh perusahaan kepada keluarga yang ditunjuknya.

b. Memperoleh makanan dan penginapan yang layak di atas kapal selama mereka bekerja di kapal. Hal in! dicantumkan dalam Pasal 5 PKL bahwa pengusaha kapal diharuskan menyediakan makanan dan tempat tidur yang layak bagi Awak Kapal sesuai dengan jabatannya di atas kapal. Akomodari Awak Kapal di atas kapal hams memenuhi persyaratan keamanan dan kesejahteraan Awak Kapal sesuai dengan Bagian Kelima Peraturan Pemerintah No. 7 tahun 2000, tentang Kepelautan. Menurut Syarifuddin mengatakan bahwa makanan dan akomodasi di atas kapal cukup memadai. 
Rahmatullah mengatakan bahwa selama ini jarang terjadi pengaduan buruh kapal mengenai kurangnya fasilitas yang seharusnya diterima di kapal.

c. Mendapatkan hak cuti apabila telah bekerja minimal selama 1 tahun. Setiap Awak Kapal berhak mendapatkan cuti tahunan paling sedikit 20 hari kalender untuk setiap jangka waktu 1 tahun bekerja (Pasal 24 Peraturan Pemerintah No. 7 tahun 2000, tentang Kepelautan). Ateng mantan ABK (wawancara, Februari 2013) mengatakan bahwa pada saat cuti mereka tetap mendapatkan gaji namun tidak mendapatkan tunjangan-tunjangan. Dalam hal ini Awak Kapal berhak cuti atau tidak. Menurut Bahar yang bekerja Kantor Kelautan Kapal menambahkan bahwa tidak pernah adapengaduan buruh kapal mengenai t/dak diberikannya gaji pada saat sedang cuti.

d. Mendapatkan perawatan dan pengobatan selama berada dikapal apabila jatuh sakit dalam menjalankan tugasnya. Dalam hal ini, menuruh Syarifuddin bahwa kapal-kapal yang pernah ia bekerja semua telah dilengkapi obat-obatan. Dan ketika ABK mengalami kecelakaan kerja selama perjalanan di laut, ABK tersebut sebelumnya mendapatkan perawatan selama di kapal, dan setelah kapal sandar di pelabuhan maka pengusaha kapal menunjuk rumah sakit untuk melanjutkan perawatan ABK yang bersangkutan. Semua biaya-biaya perawatan dan pengobatan ABK tersebut ditanggung oleh perusahaan kapal yang bersangkutan.

e. Berhak mendapatkan ganti kerugian selama menganggur akibat kecelakaan kapal. Hal ini diatur dalam Pasal 27 ayat 2 Peraturan Pemerintah Nomor 7 Tahun 2000 tentang Kepelautan, apabila terjadi pemutusan hukum dan/atau pengusaha angkutan diperairan karena kapal dianggurkan atau dijual pengusaha pengangkutan diperairan wajib membayar pesangon kepada Awak Kapal sesuai dengan perundang-undangan yang beriaku. Hal demikian dibenarkan oleh (swan Ibrahim mengatakan bahwa perusahaan memberikan ganti rugi dalam bentuk uang yang pantaskepada buruh yang menganggur akibat kecelakaan sampai ia dipekerjakan kembali.

f. Menghentikan hubungan kerja dengan pengusaha kapal. Rismawan sehubungan dengan hal tersebut ia menghentikan hubungan kerja dengan perusahaan kapal dengan alasan ingin melanjutkan pendidikannya. Sebelum ia menghentikan hubungan kerja oleh perusahaan kapal tempat ia bekerja pernah dijelaskan mengenai hal tersebut, bahwa apabila Awak Kapal menghentikan hubungan kerja maka perusahaan akan menanggung biaya pemulangan dengan syarat hak-haknya akan berhenti sejak tanggal ia turun dari kapal.

Setiap kapal yang hendak melakukan pelayaran atau sementara berlayar ditinjau dari sudut keamanan dan keselamatannya harus diawaki secukupnya dengan Awak Kapal yang cakap untuk melakukan tugasnya masing-masing. Kecakapan dan keterampilan Awak Kapal, dikualifikasikan atas beberapa jenis ijasah 
yang diharuskan dan sah sesuai dengan ukuran kapal dan daerah pelayaran yang akan dilalui.

Berdasarkan hal tersebut, maka perlu dipikirkan upaya mengatasi masalah yang berkaitan dengan sifat manusiawi tersebutyang berada dan bertugas dikapal dengan memberikan keterampilan dan pengetahuan yang lebih luas mengenai perkembangan teknologi perkapalan, melalui pendidikan dart tatiharr.Dalam hal rnt, IMO telah menyusun dan memberikan sertifikat keterampilan bagi jurusan dek dan mesin.Untuk keseragaman pendidikan dan pelatihan bagi pelaut yang bekerja di atas kapal.

Disamping kecakapan dan keteramprlan Awak Kapal yang dituntut untuk menjamin keselamatan kapal, maka perlu diperhatikan perlengkapan-perlengkapan lain yang dibutuhkan bagi kapal, dan sebagai salah satu syarat untuk melakukan pelayaran. Antara lain ialah sejumlah alat penolong (Sekoci), alat pemadam kebakaran dan radio telegrapi. Setiap alat-alat penolong seperti rakit penolong, pelampung, baju penolong dan lain-lain harus memenuhi persyaratan keselamatan dan jumlah yang dipersyaratkan untuk kapal. Tata cara penempatan dan pemberian tanda-tanda harus selalu dalam keadaan lengkap sehinga dapat dengan cepat dan mudah digunakan sesuai fungsinya pada saat diperlukan.

\section{E. KESIMPULAN DAN SARAN}

1. Kesimpulan

- Perjanjian kerja merupakan landasan utama bagi pekerja dan atau buah untuk mengadakan suatu hubungan kerja, serta merupakan dasar bagi pekerja dan atau buruh untuk menuntut hak-haknya. Bila dibandingkan Perjanjian Kerja Laut dengan Perjanjian Kerja yang berdasarkan UndangUndang akan ditemui suatu perbedaan. Perjanjian Kerja Laut bersifat khusus, sedangkan perjanjian kerja yang berdasarkan Undang-Undang bersifat umum. Perjanjian Kerja Laut harus dibuat dihadapan pejabat pemerintah yang berwenang yaitu Syahbandar.

- Dalam pengoperasian kapal laut, ditegaskan bahwa kapal harus dalam keadaan laiklaut dan diawaki oleh sejumlah Awak Kapal yang telah memenuhi persyaratan untuk berlayar. Awak Kapal dan pengusaha kapal harus menyadari hak dan kewajiban masing-masing, sehingga tercipta hubungan kerja yang selaras diantara kedua belah pihak. Pengusaha kapal juga harus memperhatikan kesejahteraan hidup pekerjanya.

\section{Saran -Saran}

- Dalam pembuatan perjanjian kerja laut diharapkan memenuhi peraturan yang telah ditetapkan sehingga tidak menimbulkanpermasalahan diantara pekerja dan pengusaha. Pihak pengusaha harus memperhatikan kesejahteraan Awak Kapal dan keluarganya. 
- Untuk lebih meningkatkan keamanan dan keselamatan kerja Awak Kapal dalam pelayaran, haruslah memperhatikan syarat-syarat dalam melakukan pelayaran. Ini dimaksudkan untuk mencegah terjadinya musibah di laut dan demi tercapainya peningkatan terhadap keselamatan kapal, muatan, dan jiwa manusia di laut.

\section{Daftar Pustaka}

Hadi. 2007. Peraturan Pelaksanaan Undang-Undang Ketenagakerjaan.Haryarindo. Jakarta.

Kansil, C.S.T., dan Christine, S.T.K. 2006. Pokok-Pokok Pengetahuan Hukum Dagang Indonesia.Sinar Grafika. Jakarta.

Kadir, A.M. 2002. Hukum Pengangkutan Niaga. PT Citra Aditya Bakti, Bandung.

Kartini, M. 2003. Perikatan yang Lahir dan Perjanjian.PT. Raja Grafindo Persada, Jakarta.

Kartosapoetra, G. 1998. Hukum Perburuan di Indonesia Berdasarkan Pancasila.Sinar Grafika. Jakarta.

Niniek Suparni. 2000. Kitab Undang-Undang Hukum Perdata.Rineka Cipta, Jakarta.

Poerwosutjipto, H.M.N. 1993. Pengertian Pokok Hukum Dagang Indonesia (Jilid 5 Hukum Pelayaran Laut dan Perairan Darat). Djambatan, Jakarta.

Redaksi Sinar Grafika. 2001. Propenas 2000-2004. Sinar Grafika. Jakarta.

2007. Undang-Undang Rencana Pembangunan Jangka Panjang Nasional tahun 2005-2025.Sinar Grafika. Jakarta.

Soedjono Wiwoho. 1982. Hukum Perkapalan dan Pengangkutan Laut.Bina Aksara, Jakarta.

Subekti, R. 1990. Hukum Perjanjian. PT. Intermasa. Jakarta.

Sudarsono. 2005. Kamus Hukum (Edisi Baru). Rineka Cipta. Jakarta. Tim Redaksi "Permata Press". 2007. Undang-Undang Ketenagakerjaan Edisi Tertangkap. Permata Press. Jakarta.

Tim Redaksi "Citra Umbara". 2007. Kitab Undang-Undang Hukum Dagang. Citra Umbara. Bandung. 